\begin{tabular}{l|l|l} 
Jurnal Eksplorasi Akuntansi & $\begin{array}{l}\text { e-ISSN : 2656-3649 (Online) } \\
\text { hol. 3, No 3, Agustus 2021, Hal 583-598 }\end{array}$
\end{tabular}

\title{
Pengaruh Intelllectual Capital dan Corporate Social Responsibility terhadap Nilai Perusahaan Pertambangan yang Terdaftar di BEI Tahun 2018-2020
}

\author{
Faulin Adelina $^{1^{*}}$, Fefri Indra Arza ${ }^{2}$ \\ ${ }^{1,2}$ Fakultas Ekonomi, Universitas Negeri Padang \\ *Korespondensi: faulinadelina0896@gmail.com
}

\begin{abstract}
This study was to determine the influence of intellectual capital and corporate social responsibility on firm value. This research method is quantitative. The population in this study is the mining sector companies on the Indonesia Stock Exchange from 2018 to 2020. The sample of this study was determined by purposive sampling. Data analysis techniques for hypothesis testing using multiple regression analysis. The results show that intellectual capital has no significant effect as well as corporate social responsibility on firm value. This is due to the low interest of investors in other aspects outside of physical and financial assets. investors are more focused on maximizing profit as a short term goal. it can be suggested that: (1) Companies should increase their assets to increase company size so that companies have more financial funds to manage their IC performance and create more added value, and (2) For future researchers, it is recommended to increase the number of sample companies, adding other variables and using other proxies in further research.
\end{abstract}

Keywords : firm value; intellectual capital; corporate social responsibility.

How to cite (APA $6^{\text {th }}$ style)

Adelina, Faulin \& Arza, F. I. (2021). Pengaruh Intelllectual Capital dan Corporate Social Responsibility terhadap Nilai Perusahaan Pertambangan yang Terdaftar di BEI Tahun 2018-2020. Jurnal Eksplorasi Akuntansi. 3(3). 583-598.

\section{PENDAHULUAN}

Nilai perusahaan adalah konsep yang penting bagi investor. Sartono (2010) mengartikan nilai perusahaan sebagai nilai jual dari perusahaan itu saat sedang beroperasi. Menurut Noerirawan (2012) nilai perusahaan merupakan nilai yang didapat perusahaan yang berupa wujud atas kepercayaan masyarakat terhadap usaha yang telah dilakukan oleh perusahaan selama tahun-tahun produksinya. Ada banyak faktor yang mempengaruhi nilai perusahaan, salah satunya adalah dengan memperlihatkan keunggulan perusahaan dalam mencapai tujuan jangka panjang perusahaan (Anggraini, 2006). Untuk mempertahankan peningkatan nilai perusahaan, perusahaan dituntut untuk tidak lagi hanya berfokus pada laba yang didapatkan. Perusahaan harus bisa mempertimbangkan aspek lain di luar aspek fisik dalam meningkatkan nilai perusahaan secara berkelanjutan.

Erawati dan Sudana (2009) mengatakan bahwa intangible asset merupakan poin yang harus diperhatikan perusahaan untuk mempertahankan dan mencapai tujuan jangka panjang perusahaan. Fajarini (2012) menyatakan intangible asset punya peran dan kontribusi yang 
penting dalam memperlihatkan perbandingan nilai buku dan nilai pasar dari perusahaan. Intangible asset akan membawa pengaruh dalam penilaian perusahaan di mata pasar. Perusahaan yang mempunyai basis di bidang ilmu pengetahuan, akan menciptakan cara agar dapat mengelola pengetahuan sebagai sarana untuk memperoleh penghasilannya (Dewi, 2014). Dengan kemajuan teknologi yang terjadi saat ini, perusahaan mulai menyadari bisnis yang didasarkan pada tenaga kerja (labor based business) harus mampu berubah ke bisnis berdasarkan pengetahuan (knowledge based business) untuk dapat tetap bersaing dengan perusahaan lainya.

Nuryaman (2015) mengatakan pendekatan yang dinilai paling baik dalam mengukur intangible asset adalah dengan menggunakan intellectual capital. Petty (2000) menyebutkan ada 4 hal yang melatarbelakangi intellectual capital menjadi begitu penting dalam hal mempengaruhi nilai perusahaan, yaitu: 1) adanya revolusi dalam teknologi dan komunikasi informasi, 2) peningkatan kebutuhan akan pengetahuan dan ekonomi berbasis pengetahuan, 3) adanya perubahan pola interpersonal dan komunitas jaringan, dan 4) adanya tuntutan inovasi sebagai penentu utama dalam daya saing. Dapat disimpulkan, alasan digunakannya variabel intellectual capital dalam mempengaruhi nilai perusahaan dianggap penting karena intellectual capital memiliki fokus dalam berbagai bidang, baik manajemen, teknologi informasi, sosiologi, maupun akuntansi.

Teori stakeholder menyatakan bahwa perusahaan bukanlah satu-satunya entitas yang beroperasi untuk kepentingan sendiri, tetapi harus memberikan manfaat kepada para pemangku kepentingan menjadikan peran perusahaan adalah untuk terus meningkatkan nilai perusahaan demi kepentingan para pemegang saham (Martini et al., 2015). Peningkatan nilai perusahaan akan menarik minat investor agar tetap percaya dan berinvestasi pada perusahaan. Ernest dan Young (1999) meyakini bahwa teori stakeholder menganggap perusahaan yang punya komitmen dalam melaporkan aktivitasnya termasuk intellectual capital mereka, akan mampu mempertahankan keseimbangan dan keberlanjutan pembentukan nilai perusahaan. Pemanfaatan sumber daya intelektual secara efektif dan efisien akan mendorong kemampuan pengembangan bagi perusahaan (Solikhah \& Merianto, 2010).

Nilai perusahaan akan diukur dengan Tobin's Q. Tobin's Q dinilai sebagai pengukuran nilai perusahaan yang lebih unggul. Tobin's $\mathrm{Q}$ mampu menjelaskan nilai perusahaan secara keseluruhan (Smithers dan Wright, 2007). Tobin's Q dikatakan dapat mencerminkan modal intelektual dari suatu perusahaan serta mengatasi masalah dengan memperkirakan tingkat keuntungan atau biaya marjinal perusahaan. Chen (2005) mengatakan nilai perusahaan diduga akan mengalami kenaikan sejalan dengan peningkatan pengakuan dari peran intellectual capital pada perusahaan. Intellectual capital akan diukur dengan menggunakan metode value added intellectual coefficient (VAIC ${ }^{\mathrm{TM}}$ ) yang diperkenalkan oleh Pulic tahun 1998. VAIC ${ }^{\mathrm{TM}}$ digunakan dalam pengukuran intellectual capital karena VAIC ${ }^{\mathrm{TM}}$ dapat menilai efisiensi dari nilai tambah yang merupakan hasil dari kemampuan intellectual capital (Hadiwijaya, 2013).

Sejalan dengan arah bisnis yang menuju berbasis ilmu pengetahuan, perusahaan pada saat sekarang juga dituntut untuk tidak hanya melakukan usaha dengan tujuan peningkatan profit saja. Tanggung jawab perusahaan saat ini sampai pada tingkat tanggung jawab sosial dan lingkungan perusahaan. Bramantya (2010) menyatakan jika saat ini Indonesia memberikan perhatian khusus pada tanggung jawab sosial dan lingkungan yang dilakukan perusahaan. Perusahaan dituntut untuk memiliki rasa menghargai terhadap orang lain ataupun lingkungan (Chahal, 2006). Corporate social responsibility menjadi salah satu cara perusahaan untuk memperhatikan aspek lingkungan dan sosial perusahaan.

Secara umum CSR dipandang sebagai bentuk kesukarelaan yang dilakukan perusahaan sebagai komitmen dalam kontribusi untuk pembangunan ekonomi berkelanjutan. Trend masa kini menunjukkan konsumen menaruh perhatian pada lingkungan dan menjadikan perusahaan yang menjalakan CSR dilirik oleh konsumen dan investor. Namun begitu, secara 
hukum CSR telah diatur dengan tegas oleh pemerintah dalam UU PT No.40 tahun 2007. Oleh karena itu, pelaksanaan CSR sebagai kewajiban akan menigkatkan nilai perusahaan sekaligus menjadi beban bagi perusahaan pada saat bersamaan . Untuk itu, variabel CSR dianggap penting dalam menentukan nilai perusahaan.

Dengan melakukan CSR, perusahaan dapat membangun citra dan nama baiknya yang akan menaikkan nilai perusahaan di masa depan (Prita, 2017). Pengungkapan CSR dalam jangka waktu yang lama akan menaikkan citra dari perusahaan. Kenaikan citra ini akan menaikkan loyalitas konsumen pada perusahaan. Menurut Satyo (2005) dalam Sutopoyudo (2009) peningkatan loyalitas dari konsumen akan berimbas pada kenaikan penjualan dan berujung pada kenaikan nilai perusahaan.

Stakeholder teori meyakini keberadaan suatu perusahaan sangat dipengaruhi oleh dukungan yang diberikan oleh stakeholder kepada perusahaan tersebut. Gray dalam Totok (2014) mengatakan bahwa kelangsungan hidup perusahaan tergantung pada apa yang menjadi dukungan stakeholder. Oleh karena itu aktivitas perusahaan adalah untuk mencari dukungan tersebut. Semakin besar kekuatan stakeholder maka semakin besar usaha perusahaan untuk beradaptasi. Corporate social responsibility dianggap sebagai bagian dari dialog antara perusahaan dengan stakeholdernya (Handoko, 2014). CSR diukur dengan corporate social responsibility indeks yang disyaratkan oleh GRI G4 yang berjumlah 91 item pengungkapan. GRI G4 dijadikan pengukuran karena GRI G4 dianggap sebagai pengukuran yang paling relevan dengan tahun penelitian. GRI G4 mencakup item-item yang diperlukan dalam menilai kegiatan CSR perusahaan.

Beberapa penelitian terdahulu banyak yang menghubungkan pengaruh dari intellectual capital serta CSR terhadap nilai perusahaan, namun terdapat hasil yang berbeda-beda pada setiap penelitian terdahulu. Penelitian yang dilakukan oleh Yuskar dan Dhia (2014) serta Rendy dan Abdul (2013) yang meneliti tentang pengaruh intellectual capital terhadap nilai perusahaan memperlihatkan hasil jika intellectual capital tidak mempunyai pengaruh secara langsung terhadap nilai perusahaan. Berbeda dengan penelitian yang dilakukan oleh Norma Fauzia (2016) serta Putri et.al (2019) yang mendapatkan hasil penelitian menunjukkan jika intellectual capital berpengaruh positif dan signifikan terhadap nilai perusahaan. Selanjutnya penelitian yang dilakukan oleh Anindita dan Yuliati (2017) serta Norma Fauzia (2016) yang meneliti tentang pengaruh CSR terhadap nilai perusahaan mendapatkan hasil jika CSR berpengaruh positif signifikan terhadap nilai perusahaan. Namun hasil berbeda di tunjukkan oleh penelitian yang dilakukan oleh Setianingrum (2015) yang mendapatkan hasil jika CSR tidak berpengaruh terhadap nilai perusahaan.

Ketidakkonsistenan hasil penelitian membuat peneliti tertarik untuk menguji kembali pengaruh variabel intellectual capital dan CSR terhadap nilai perusahaan. terdapat beberapa perbedaan pada penelitian ini dengan penelitian sebelumnya. Tahun penelitian serta sektor perusahaan yang berbeda memungkinkan mendapatkan hasil yang berbeda juga. Indeks untuk mengukur CSR pada penelitian kali ini menggunakan indeks yang paling relevan dengan tahun penelitian yaitu GRI G4 dengan 91 item pengungkapan.

Penelitian ini bertujuan untuk mengetahui pengaruh dari intellectual capital dan corporate social reponsibility terahdap nilai perusahaan pada perusahaan pertambangan yang terdaftar di BEI tahun 2018-2020. Alasan pemilihan sektor pertambangan sebagai populasi penelitian dikarenakan; 1) Sektor tambang merupakan penyedia kebutuhan akan energi maupun tambahan bahan baku bagi kegiatan industri dalam negeri. Sektor tambang juga merupakan penghasil tambahan devisa pembangunan dan penyedia lapangan kerja yang besar di Indonesia. Oleh karena itu, sektor tambang dimasukkan menjadi pilar ekonomi nasional. Dengan begitu, sektor tambang dapat dikategorikan menjadi usaha yang high profile (Hackston dalam Anggraini, 2006). Informasi sosial akan lebih banyak didapat pada perusahaan yang high profile dibanding perusuhaan yang low-profile (Anggraini, 2006). 2) 
Sektor pertambangan tepat untuk penelitian dengan menggunakan CSR, karena kegiatan usaha sektor pertambangan bersinggungan langsung dengan alam dan lingkungan sosial, sehingga semua data yang dibutuhkan akan dengan sangat intensif dilaporkan pada perusahaan pertambangan.

\section{REVIU LITERATUR DAN HIPOTESIS Stakeholder Theory}

Kasali (1994) menyakan bahwa stakeholder adalah setiap kelompok yang ada di dalam maupun di luar perusahaan yang memiliki peran dalam menentukan keberhasilan suatu perusahaan. Teori stakeholder bertujuan dalam membantu manager korporasi memahami situasi stakeholder mereka. Pengelolaan yang lebih efektif pada situasi perusahaan juga merupakan tujuan lain dari teori ini. Dalam lingkup lebih luas, tujuan dari teori ini adalah sebagai penolong bagi manajer korporasi dalam menaikkan nilai atas aktifitas perushaan serta menurunkan kerugian yang akan dialami stakeholder (Ulum, 2009).

Stakeholder memiliki kemampuan untuk mengatur dan mengendalikan pemakaian atas sumber ekonomi perusahaan (Ghozali dan Chariri, 2007). Kemampuan stakeholder dalam mengendalikan sumber ekonomi yang penting bagi perusahaan menjadikan perusahaan akan dengan sendirinya mencari cara-cara untuk memuaskan keinginan stakeholder.

Dalam menjelaskan hubungan intellectual capital dengan nilai perusahaan, stakeholder teori dapat dipandang dari dua sisi; etika dan manajerialnya. Dalam padangan etika, dinyatakan bahwa seluruh stakeholder memiliki hak untuk diperlakukan secara adil oleh organisasi dan manajer diharuskan untuk mengelola organisasi untuk keuntungan seluruh stakeholder (Deegan, 2004). Dalam pandangan manajerial, kekuatan stakeholder yang mampu mempengaruhi manajemen operasi merupakan fungsi dari tigkat pengendalian stakeholder atas sumber daya yang dibutuhkan organisasi (Watts dan Zimmerman, 2012).

Dalam menjelaskan hubungan CSR dengan nilai perusahaan, teori stakeholder mengisyaratkan jika perusahaan hendaknya memperhatikan stakeholder mereka. Hal ini dikarenakan stakeholder merupakan pihak yang paling mempengaruhi serta dipengaruhi bisa secara langsung atau tidak atas segala aktivitas serta kebijakan yang diambil dan dilakukan perusahaan. Ketika perusahaan tidak memperhatikan stakeholdernya, perusahaan akan mendapatkan protes serta legitimasi mereka akan dianggap tidak ada oleh stakeholder (Susanti,2014). Keberadaan suatu perusahaan sangat dipengaruhi oleh dukungan yang diberikan stakeholder kepada perusahaan tersebut (Rosiana dkk, 2013). Dalam mengungkapkan CSR perusahaan diaharapkan tidak hanya terbatas pada tindakan memaksimalkan laba untuk pemegang saham semata. Untung (2008) menyatakan perusahaan harus lebih menitikberatkan pada kesejahteraan untuk semua pihak yang mempunyai keterkaitan dan klaim terhadap perusahaan.

\section{Resources Based View (RBV)}

Perusahaan yang memiliki keunggulan kompetitif ditandai dengan tingginya kemamapuan pengelolaan sumber daya yang dimiliki oleh perusahaan serta memiliki pengetahuan yang baik atas sumber daya itu. (Kuryanto, 2008). Sumber daya fisik, manusia, serta organisasi adalah bagian dari organisasi itu sendiri (Madhani, 2010). Dalam menjelaskan hubungan intellectual capital dengan nilai perusahaan, Wernerfelt (1984) mengatakan dalam RBV teori, perusahaan akan memperoleh keunggulan kompetitif dan nilai perusahaan yang baik dengan cara memiliki, menguasai dan memanfaatkan aset-aset strategis baik itu asset berwujud maupun tidak berwujud. Pulic (1998) berpendapat bahwa tujuan utama perekonomian berbasis pengetahuan adalah menciptakan nilai tambah. Untuk itu diperlukan modal fisik yang berupa dana keuangan dan potensi intelektual berupa karyawan dan segala potensi dan 
kemampuan perusahaan yang ada. Dengan begitu, sumber daya yang dimilliki perusahaan akan dapat meningkatkan nilai perusahaan.

\section{Teori Legitimasi}

Teori legitimasi memandang jika suatu hal itu diharapkan oleh komunitas, maka perusahaan akan secara sukarela untuk melaporkan aktivtasnya (Deegan, 2004). Norma yang berlaku di masyarakat menjadi patokan organisasi dalam menjalankan perusahaan secara berkelanjutan. Pada teori legitimasi pengungkapan informasi dalam laporan keuangan dititikberatkan pada persepsi dan pengakuan publik.

Dalam menjelaskan CSR dengan nilai perusahaan, legitimasi teori menyebut jika CSR adalah bentuk dari aktivitas perusahaan untuk meningkatkan ekonomi perusahaan sekaligus meningkatkan kualitas kehidupan karyawan serta keluarganya dan juga masyarakat sekitar. CSR tidak semata-mata hanya untuk masyarakat sekitar, namun juga pada stakeholdernya karena merupakan pihak yang keberadaannya paling penting dalam mempengaruhi dan dipengaruhi perusahaan.

\section{Intellectual Capital dan Nilai Perusahaan}

Nilai dari suatu perusahaan dapat tercermin pada harga saham yang dibayar investor atas sahamnya di pasar. Chen et al. (2005) menemukan bahwa terdapat hubungan yang positif antara intellectual capital dengan nilai pasar perusahaan. Ketika intellectual capital meningkat, dalam artian dikelola dengan baik, hal ini dapat meningkatkan persepsi pasar pada nilai perusahaan. Intellectual capital dibentuk dari penjumlahan potensi sumberdaya pengetahuan perusahaan. Pada potensi dari asset fisik, modal yang tersedia dapat menaikkan nilai tambah bagi perusahaan. Modal yang lebih besar memungkinkan untuk meningkatkan pendapatan perusahaan yang akan berpengaruh pada peningkatan value added bagi perusahaan. Pada potensi dari segi human capital, gaji dan tunjangan karyawan yang lebih besar akan seiring dengan penjualan yang meningkat. Besarnya tunjangan dan gaji yang diberikan diharapkan akan menjadi motivasi karyawan untuk meningkatkan produktivitasnya.

Dengan begitu, pendapatan serta profit dari perusahaan juga akan mengalami peningkatan karena produktivitas perusahaan yang meningkat. Pada potensi dari segi structural capital, segala jenis infrastruktur pendukung human capital dalam menjalakan aktivitas-aktivitasnya haruslah dipenuhi. Ketika infrastruktur yang dibutuhkan telah dilengkapi, berarti secara efisien perusahaan telah mampu memenuhi proses rutinitas perusahaan dan strukturnya secara efisien. Ketika ketiga potensi ini mampu dipenuhi oleh perusahaan, persepsi pasar terhadap nilai perusahaan akan meningkat karena diyakini bahwa perusahaan yang memiliki keunggulan kompetitif mampu bersaing dan bertahan dilingkungan bisnis yang dinamis.

Chen et al.,(2005) telah meneliti hubungan antara intellectual capital pada nilai perusahaan dan kinerja keuangan pada perusahaan publik di Taiwan dengan periode waktu 1992-2002. Chen mendapatkan hasil jika intellectual capital berpengaruh positif terhadap nilai pasar dan kinerja keuangan. Kesimpulan yang sama ditemukan pada penelitian Ulum (2008) yang meneliti hubungan intellectual capital terhadap kinerja perusahaan perbankan Indonesia. Hasil penelitian menunjukkan bahwa Intellectual Capital berpengaruh signifikan positif terhadap kinerja perusahaan sekarang dan masa depan. Berdasarkan uraian tersebut, maka hipotesis yang diajukan adalah:

H1: intellectual capital berpengaruh terhadap nilai perusahaan

\section{Corporate Social Responsibility dan Nilai Perusahaan}

CSR merupakan bentuk dari pertanggungjawaban yang dilakukan perusahaan kepada segenap stakeholder di lingkungan sosial dan lingkungan hidup dalam hal yang berkaitan 
dengan kegiatan operasi perusahaan. Pada masa kini, perusahaan dituntut untuk tidak lagi hanya berfokus pada bentuk tanggung jawab keuangan saja, namun juga harus memperhatikan tanggung jawab dimensi keuangan, lingkungan dan sosial. Berdasarkan teori legitimasi, perusahaan harus memberikan pengungkapan aktivitas sosial yang kemudian akan menjamin keberlangsungan hidup perusahaan serta membuat keberadaannya dapat diterima di masyarakat dengan seluruh kegiatan operasinya. Pandangan masyarakat terhadap perusahaan yang memiliki citra yang baik akan menarik konsumen untuk mau menggunakan produk dari perusahaan.

Nilai perusahaan dapat diartikan sebagai acuan dari investor terhadap minat investasi pada perusahaan. Nilai perusahaan dapat dilihat pada harga saham dan laba perusahaan sebagai akibat dari para investor yang menanamkan saham pada perusahaan. Corporate social responsibility yang telah dilaksanankan perusahaaan dapat dijadikan strategi untuk memberi image yang baik dari perusahaan kepada pihak eksternal. Dengan begitu, perusahaan akan dapat memaksimalkan modal pemegang saham, reputasi perusahaan, dan keberlangsungan perusahaan dalam jangka panjang. Dengan adanya dukungan dari lingkungan pada perusahaan, perusahaan akan memperoleh eksistensi serta reputasi yang baik yang akan meningkatkan nilai perusahaan. oleh karena itu CSR dianggap akan menaikkan nilai perusahaan.

Menurut Maemunah (2005) pengungkapan CSR mampu memaksimalkan kekuatan keuangan secara jangka panjang serta mampu memperoleh legitimasi sosial perusahaan. Penelitian yang dilakukan oleh Ni Wayan Rustiarini (2008) menemukan bahwa CSR mempunyai pengaruh positif signifikan atas nilai perusahaan. penelitian oleh Anindita dan Yuliati (2017) dan Norma Fauzia (2016) juga menunjukkan hasil yang sama bahwa CSR berpengaruh positif dan signifikan terhadap nilai perusahaan. Berdasarkan uraian tersebut, maka hipotesis yang diajukan adalah:

H2: Corporate social responsibility berpengaruh terhadap nilai perusahaan.

\section{METODE PENELITIAN}

Metode penelitian ini adalah metode kuantitatif. Penelitian ini difokuskan pada perusahaan sektor pertambangan yang terdaftar dalam BEI untuk periode tahun 2018-2020. Sektor tambang dipilih karena: 1) sektor tambang adalah industri yang termasuk dalam kategori high-profile sehingga dianggap sebagai pilar ekonomi nasional dan informasi sosial akan lebih banyak didapat pada perusahaan yang dikategorikan high-profile dibanding perusahaan low-profile. 2) kegiatan pada sektor pertambangan bersinggungan langsung dengan alam dan lingkungan sosial, sehingga tanggung jawab perusahaan terhadap lingkungan dan sosial wajib dijalankan dengan melaksanakan CSR-nya. Teknik pengambilan sampel yang digunakan berupa purposive sampling dengan total perusahaan yang diteliti sebanyak 33 perusahaan dalam waktu 3 tahun. Teknik pengumpulan data yang digunakan adalah data sekunder dengan teknik analisis data yang dilakukan adalah uji analisis regresi berganda dengan bantuan SPSS versi 25.0 dan sebelumnya telah lulus uji asumsi klasik.

Tabel 1

Kriteria Pemilihan Sampel

\begin{tabular}{lcc}
\hline \multicolumn{1}{c}{ Keterangan } & Jumlah & $\begin{array}{c}\text { Jumlah } \\
\text { Sample }\end{array}$ \\
\hline $\begin{array}{l}\text { Perusahahan pertambangan yang terdaftar di Bursa Efek Indonesia tahun } \\
2019-2020\end{array}$ & 49 & 49 \\
$\begin{array}{l}\text { Perusahaan pertambangan yang tidak menyediakan laporan keuangan dan } \\
\text { tahunan lengkap selama tahun 2019-2020 }\end{array}$ & 8 & 41
\end{tabular}


Variabel dependen pada penelitian ini adalah nilai perusahaan yang diukur dengan menggunakan metode Tobin's Q. Tobin's Q dirumuskan sebagai berikut:

$$
\text { Tobin's } \mathbf{Q}=\frac{\text { EMV }+\mathrm{D}}{\text { EBV }+\mathrm{D}}
$$

Variabel intellectual capital dapat dihitung menggunakan metode VAIC ${ }^{\mathrm{TM}}$. Variabel CSR dapat dihitung dengan indeks pengungkapan yang didasarkan pada GRI G4 dengan 91 item pengungkapan.

\section{HASIL DAN PEMBAHASAN Statistik Deskriptif}

Tabel 2

Descriptive Statistics

\begin{tabular}{|c|c|c|c|c|c|}
\hline & $\mathrm{N}$ & Minimum & Maximum & Mean & Std. Deviation \\
\hline nilai perusahaan(Y) & 99 & 0.4723 & 82.2438 & 8.535552 & 11.9866211 \\
\hline VAICtm (X1) & 99 & -5.2436 & 11.7324 & 3.204668 & 2.8694126 \\
\hline CSRi(X2) & 99 & 0.2088 & 0.5604 & 0.405150 & 0.0737608 \\
\hline Valid N (listwise) & 99 & & & & \\
\hline
\end{tabular}

Tabel 2 di atas menjelaskan secara deskriptif variabel-variabel dalam penelitian ini. Variabel nilai perusahaan (Y) memiliki rata-rata sebesar 8,5356 dan standar deviasi 11,9866. Nilai perusahaan tetinggi dimiliki oleh Harum Energy tbk di tahun 2018 terjadi pada angka 82.24 dan yang terendah adalah 0,47 yang dimiliki oleh perusahaan Perdana Karya Perkasa Tbk untuk tahun 2020. Variabel VAIC ${ }^{\mathrm{TM}}$ memiliki rata-rata sebesar 3.2046 dan standar deviasi 2.8694. VAIC ${ }^{\text {TM }}$ tertinggi berada pada angka 11,7324 yang dimiliki oleh perusahaan Cita Mineral Investindo Tbk untuk tahun 2020, dan nilai terendah dipeoleh oleh perusahaan Golden Eagle Energy Tbk untuk tahun 2020 pada angka -5,2436. Variabel CSR memiliki rata-rata sebesar 0,4052 dan standar deviasi 11,9866. Csr tertinggi berada pada angka 0,5604 yang dimiliki oleh perusahaan Adaro Energy Tbk untuk tahun 2020 dan nilai terendah berada pada angka 0.2088 yang dimiliki oleh perusahaan Perdana Karya Perkasa Tbk untuk tahun 2020 .

\section{Uji Asumsi Klasik}

Tujuan dari uji normalitas residual ini adalah untuk menguji apakah dalam sebuah model regresi, variabel pengganggu atau residual data penelitian ini dilakukan dengan menggunakan one sample kolmogrov-smirnov test, yang mana jika nilai asymp.sig (2-tailed) $>0,05$, maka distribusi residual dikatakan normal. Berdasarkan tabel 3, dapat diketahui bahwa hasil uji normalitas menunjukkan level signifikansi lebih besar dari $\alpha(\alpha=0,05)$ yaitu 0,100 $>0,05$ yang berarti residual terdistribusi secara normal. 
Tabel 3

Hasil Uji Normalitas

\begin{tabular}{lll}
\hline & & Unstandardized Residual \\
\hline $\mathrm{N}$ & & 99 \\
Normal Parameters & Mean & 0.0000000 \\
Most Extreme Differences & Std. Deviation & 1.11649908 \\
& Absolute & 0.082 \\
& Positive & 0.074 \\
Test Statistic & Negative & -0.082 \\
Asymp. Sig. (2-tailed) & & 0.082 \\
\hline
\end{tabular}

Gejala multikolniearistas ditandai dengan adanya hubungan yang kuat di antara variabel independen (bebas) dalam suatu persamaan regresi. Model regresi dinyatakan bebas dari multikolinearitas apabila nilai VIF $<10$ nilai tolerance $>0,10$. Berdasarkan Tabel 4 di bawah, dapat dilihat hasil perhitungan VIF dan tolerance.. Nilai VIF untuk variabel intellectual capital (X1) sebesar 1,011, dan corporate social responcibility (X2) sebesar 1,0111. Ini menunjukkan masing-masing variabel mempunyai nilai VIF $<10$. Pada table tolerance juga dapat dilihat masing-masing variabel intellectual capital (X1) mempunyai nilai 0.989 dan corporate social responsibility (X2) dengan nilai 0.989 yang mengartikan tolerance $>0.10$. Dapat disimpulkan tidak terdapat gejala multikolinearitas antar variabel bebas.

Tabel 4

Uji Multikolinearitas

\begin{tabular}{cccc}
\hline \multicolumn{2}{c}{ Model } & & \multicolumn{2}{c}{ Collinearity Statistics } \\
& & Tolerance & VIF \\
\hline & & & \\
1 & (Constant) & & \\
& x1 & 0.989 & 1.011 \\
& $\mathrm{x} 2$ & 0.989 & 1.011 \\
\hline
\end{tabular}

Berdasarkan Tabel 5 di bawah dapat dilihat nilai sig. dari masing-masing variabel berada pada angka lebih dari 0,05. Nilai sig. untuk variabel intellectual capital (X1) sebesar 0.105, dan corporate social responcibility (X2) sebesar 0.154. Dapat disimpulkan variabel terbebas dari heterokedastisitas.

Tabel 5

Uji Heterokedastisitas

\begin{tabular}{|c|c|c|c|c|c|c|}
\hline & \multirow[t]{2}{*}{ Model } & \multicolumn{2}{|c|}{ Unstandardized Coefficients } & \multirow{2}{*}{$\begin{array}{c}\text { Standardized } \\
\text { Coefficients } \\
\text { Beta } \\
\end{array}$} & \multirow[t]{2}{*}{$\mathrm{T}$} & \multirow[t]{2}{*}{ Sig. } \\
\hline & & $\mathrm{B}$ & Std. Error & & & \\
\hline \multirow{3}{*}{1} & (Constant) & 3.308 & 0.798 & & 4.145 & 0.000 \\
\hline & $\mathrm{x} 1$ & -0.468 & 0.286 & -0.164 & -1.637 & 0.105 \\
\hline & $\mathrm{x} 2$ & 0.860 & 0.599 & 0.143 & 1.435 & 0.154 \\
\hline
\end{tabular}

Uji autokorelasi merupakan pengujian asumsi dalam regresi dimana variabel dependen tidak berkorelasi dengan dirinya sendiri. Maksud korelasi sendiri asalah bahwa nilai dari variabel dependen tidak berrhubungan dengan variabel itu sendiri, baik nilai periode sebelumnya maupun nilai sesudahnya dengan cara pengambilan kepurtusan $\mathrm{du}<\mathrm{d}<4$-du. Berdasarkan uji autokorelasi ditemukan bahwa nilai Durbin-Watson 2.022. Nilai tabel dengan menggunakan nilai signifikansi 5\%, jumlah sampel 99 dan jumlah variabel 3, maka di tabel 
Durbin Watson di du sebesar 1,7140. Jadi nilai DW 2.045 lebih besar dari batas atas (du) dan kurang dari 4-du atau 1,7140<2.022<2,286. Ini berarti penelitian terbebas dari autokorelasi. Hasil pengujian dapat dilihat pada Tabel 7 berikut:

Tabel 7

Uji Autokorelasi

\begin{tabular}{rrrrrr}
\hline Model & $\mathrm{R}$ & R Square & $\begin{array}{c}\text { Adjusted R } \\
\text { Square }\end{array}$ & $\begin{array}{c}\text { Std. Error of the } \\
\text { Estimate }\end{array}$ & \multicolumn{2}{c}{ Durbin-Watson } \\
\hline 1 & $0.165^{\mathrm{a}}$ & 0.027 & 0.007 & 0.90889 & 2.022
\end{tabular}

a. Predictors: (Constant), LEG_X2, LEG_X1

b. Dependent Variable: LEG $\bar{Y}$

\section{Analisis Data}

\section{Uji F Statistik}

Uji F dilakukan untuk menguji apakah secara bersama-sama variabel independen mampu menjelaskan variabel dependen secara baik atau menguji apakah model yang digunakan telah fix atau tidak. Patokan yang digunakan adalah dengan membandingkan nilai sig lebih kecil dari derajat signifikan maka persamaan regresi yang diperoleh dapat diandalkan (sudak fix), seperti pada tabel 12 berikut ini:

Tabel 8

Hasil Uji F Statisik

\begin{tabular}{llccccc}
\hline & Model & Sum of Squares & Df & Mean Square & F & Sig. \\
\hline \multirow{2}{*}{1} & Regression & 6.738 & 2 & 3.369 & 2.647 & $0.076^{\mathrm{b}}$ \\
& Residual & 122.164 & 96 & 1.273 & & \\
& Total & 128.901 & 98 & & &
\end{tabular}

a. Dependent Variable: y

b. Predictors: (Constant), $\mathrm{x} 2, \mathrm{x} 1$

Hasil pengolahan data menunjukkan hasil yang tidak signifikan pada 0.076 (sig.0,0000 $<0.005$ ). Hal ini berarti bahwa persamaan regresi yang diperoleh tidak dapat diandalkan atau secara simultan Nilai Perusahaan tidak mampu dijelaskan oleh intellectual capital dan CSR.

\section{Uji Koefisien Determinasi}

Nilai $R$ Square menunjukkan 0.052 . Hal ini mengindikasikan bahwa kontribusi variabel bebas yaitu intellectual capital dan CSR terhadap variabel terikat nilai perusahaan hanya sebesar 5,2\%, sedang 94,8\% sisanya ditentukan oleh faktor lain. Nilai Adjusted R Square dapat dilihat pada tabel di bawah ini.

Tabel 9

Koefisien Determinasi

\begin{tabular}{ccccc}
\hline Model & $\mathrm{R}$ & $\mathrm{R}$ Square & Adjusted R Square & Std. Error of the Estimate \\
\hline 1 & $0.229^{\mathrm{a}}$ & 0.052 & 0.033 & 1.12807
\end{tabular}

a. Predictors: (Constant), $\mathrm{x} 2, \mathrm{x} 1$

b. Dependent Variable: $y$

\section{Persamaan Regresi Berganda}

Analisis dalam penelitian ini menggunakan model regresi berganda untuk meguji apakah pengaruh variabel-variabel independen terhadap variabel dependen. Analisis regresi berganda digunakan untuk memberikan penjelasan tentang aplikasi program SPSS 25 yang telah ditansformasikan ke dalam variabel penelitian terlihat pada tabel di bawah ini. 
Tabel 10

Hasil Regresi Berganda

\begin{tabular}{|c|c|c|c|c|c|c|c|}
\hline & Model & \multicolumn{3}{|c|}{ Unstandardized Coefficients } & $\begin{array}{c}\text { Standardized } \\
\text { Coefficients }\end{array}$ & \multirow[t]{2}{*}{$\mathrm{t}$} & \multirow[t]{2}{*}{ Sig. } \\
\hline & & $B$ & Std. Error & & Beta & & \\
\hline \multirow[t]{3}{*}{1} & (Constant) & & 3.308 & .798 & & 4.145 & 0.000 \\
\hline & $\mathrm{x} 1$ & & -0.468 & .286 & -0.164 & -1.637 & 0.105 \\
\hline & $\mathrm{x} 2$ & & 0.860 & .599 & 0.143 & 1.435 & 0.154 \\
\hline
\end{tabular}

Dari pengoalahan data statistik di atas, maka diperoleh persamaan regresi berganda sebagai berikut:

$$
\mathrm{Y}=3.308-0.468(\mathrm{X} 1)+0.860(\mathrm{X} 2)+\mathrm{e}
$$

Angka yang dihasilkan dari pengujian tersebut dijelaskan sebagai berikut:

a. Konstan $(\alpha)$

Nilai konstan yang diperoleh sebesar 3.308. Hal ini berarti jika variabel independen $(\mathrm{X} 1, \mathrm{X} 2)$ tidak ada, maka besarnya tingkat nilai perusahaan yang terjadi adalah sebesar 3.308 .

b. Koefisien regresi $(\beta) \mathrm{X} 1$

Nilai koefisien regresi variabel intellectual capital (X1) sebesar -0.468. hal ini menunjukkan bahwa setiap peningkatan satu satuan intellectual capital akan mengakibatkan kenaikan nilai perusahaan sebesar 0.468 .

c. Koefisien regresi $(\beta) \mathrm{X} 2$

Nilai koefisien regresi variabel CSR (X2) sebesar 0.860. hal ini menunjukkan bahwa setiap peningkatan satu satuan CSR akan mengakibatkan kenaikan nilai perusahaan sebesar 0.860 .

Uji $\mathrm{t}$ dilakukan untuk melihat pegaruh variabel independen terhadap variabel dependen dalam persamaan regresi secara parsial dengan asumsi variabel lain dianggap konstan. Hasil pengujian menunjukkan bahwa tingkat alpha 0.05 diperoleh kesimpulan Intellectual Capital berpengaruh pada nilai perusahaan. Dari tabel 10 dapat dilihat bahwa intellectual capital memiliki nilai signifikansi $0.105>\alpha 0,05$ dengan nilai koefisien bernilai 0.468. Dapat disimpulkan jika intellectual capital tidak berpengaruh signifikan terhadap nilai perusahaan. Dengan demikian $\mathbf{H 1}$ ditolak. Hipotesis 2 penelitian corporate social responsibility berpengaruh terhadap nilai perusahaan. Dari tabel 10, dapat dilihat nilai signifikan CSR berda pada nilai $0.154>\alpha 0.05$ dengan nilai koefisien bernilai 0.860 . Dapat disimpulkan jika intellectual capital tidak berpengaruh signifikan terhadap nilai perusahaan. Dengan demikian $\mathbf{H} 2$ ditolak.

Pengujian untuk model regresi berganda kembali dilakukan dengan menggunakan metode forward. Setelah dilakukan pengujian dengan metode forward, didapatkan hasil, hanya variabel intellectual capital yang berpengaruh pada nilai perusahaan. Variabel intellectual capital menunjukkan nilai $r$ square sebesar 0.042 atau dapat diindikasikan jika kontribusi intellectual capital pada nilai perusahaan sebesar $4,2 \%$.

Tabel 11

Koefisien Determinasi Metode Forward

\begin{tabular}{lrrrr}
\hline \multicolumn{1}{c}{ Model } & $\mathrm{R}$ & $\mathrm{R}$ Square & Adjusted R Square & \multicolumn{2}{c}{$\begin{array}{c}\text { Std. Error of the } \\
\text { Estimate }\end{array}$} \\
\hline 1 a. Predictors: (Constant), VAICtm (X1) & 0.042 & 0.032 & 11.7939991 \\
\hline
\end{tabular}


Hasil pengolahan data menggunakan metode forward untuk variabel intellectual capital terhadap nilai perusahaan berhasil menunjukkan nilai yang signifikan. Intellectual capital berada pada angka sig. $0.042<0.05$ yang mengartikan jika persamaan regresi yang diperoleh dapat diandalkan atau model yang digunakan sudah fix atau secara simultan nilai perusahaan dapat dijelaskan oleh variabel intellectual capital.

Tabel 12

Uji F Statistik Metode Forward

\begin{tabular}{llrrrrr}
\hline & Model & Sum of Squares & Df & Mean Square & F & Sig. \\
\hline 1 & Regression & 588.004 & 1 & 588.004 & 4.227 & $0.042^{\mathrm{b}}$ \\
& Residual & $13,492.546$ & 97 & 139.098 & & \\
& Total & $14,080.550$ & 98 & & & \\
\hline
\end{tabular}

Pada tabel uji $\mathrm{t}$ dengan metode forward berikut, dapat dipahami koefisien regresi sebesar 0.854 menyatakan bahwa jika intellectual capital $(\mathrm{X})$ mengalami kenaikan satu satuan, maka nilai perusahaan (Y) akan mengalami peningkatan sebesar 0.854 atau 85,4\%. H1 diterima.

Tabel 13

Regresi Berganda Metode Forward

\begin{tabular}{|c|c|c|c|c|c|c|}
\hline & \multicolumn{5}{|c|}{ Standardized } \\
\hline & & \multicolumn{2}{|c|}{ Unstandardized Coefficients } & \multirow{2}{*}{$\begin{array}{c}\text { Coefficients } \\
\text { Beta }\end{array}$} & \multirow[t]{2}{*}{$\mathrm{t}$} & \multirow[t]{2}{*}{ Sig. } \\
\hline & & $\mathrm{B}$ & Std. Error & & & \\
\hline 1 & (Constant) & 5.800 & 1.782 & & 3.255 & 0.002 \\
\hline & VAICtm (X1) & 0.854 & 0.415 & 0.204 & 2.056 & 0.042 \\
\hline
\end{tabular}

Dari pengolahan data statistik dengan metode forward di atas, maka diperoleh persamaan regresi berganda sebagai berikut:

$$
\mathrm{Y}=5.800+0.854(\mathrm{X} 1)+\mathrm{e}
$$

\section{Pembahasan}

\section{Intellectual Capital terhadap Nilai Perusahaan}

Berdasarkan hasil analisis statistik dalam penelitian ini, intellectual capital dapat membuktikan pengaruhnya terhadap nilai perusahaan. Penelitian ini sejalan dengan penelitian I Gusti, Erna dan Lilik (2016), Sunitha (2016) dan Norma (2016). Hal ini menunjukkan penilaian dari perusahaan mampu dipengaruhi oleh intellectual capital yang mampu diberikan oleh perusahaan itu. Informasi pada laporan tahunan yang didalamnya terkandung modal intelektual mampu memperlihatkan prospek perusahaan dan menjadi acuan bagi investor serta stakeholder dalam pengambilan keputusan.

Intellectual capital yang dijabarkan secara luas oleh perusahaan akan meningkatkan kepercayaan dan keyakinan dari investor bahwa perusahaan mampu mencapai nilai yang maksimal. Dengan adanya keyakinan ini, investor akan terdorong untuk melakukan perdagangan saham dengan efek nilai pasar saham ikut meningkat. Pengaruh dari intellectual capital baru akan terasa di perusahaan setelah melewati satu dua tahun pertama perusahaan berjalan. Ini terjadi karena investor memandang intellectual capital sebagai pengetahuan serta kekayaan dan pengalaman yang dapat digunakan untuk menciptakan nilai tambah yang akan berguna dalam persaingan dengan keunggulan kompetitif berkelanjutan. 


\section{Corporate social responsibility terhadap nilai perusahaan}

Berdasarkan hasil analisis statistik dalam penelitian ini, maka CSR terhadap nilai perusahaan tidak dapat membuktikan pengaruhnya. Penelitian ini bertolak belakang dengan hasil penelitian yang dilakukan oleh Anindita (2017) dan Norma (2016). Penyebab hipotesis ini ditolak adalah kegiatan CSR di Indonesia tidak terlalu diperhatikan oleh shareholder. Pada dasarnya, kegiatan CSR yang dilakukan oleh perusahaan pertambangan cenderung stabil, namun, setiap tahunnya penurunan dan kenaikan nilai perusahaan terus terjadi. Ini menunjukkan jika CSR tidak terlalu mempengaruhi nilai perusahaan. Penelitian ini tidak sesuai dengan paradigma enlightened self-interest yang menyatakan bahwa stabilitas dan kemakmuran ekonomi jangka panjang hanya akan dapat dicapai jika perusahaan juga memasukkan unsur tanggung jawab sosial kepada paling tidak dalam tingkat yang minimal (Nurhayati, 2012).

Yustia (2014) menyatakan sebagian besar perusahaan hanya berfokus pada faktor keuangan. Perusahaan kurang peduli terhadap faktor lingkungan dan sosial. CSR dianggap sebagai bagian dari beban dalam perusahaan. Dengan dianggap sebagai suatu kewajiban, investor cenderung tidak melirik pelaporan CSR sebagai keunggulan suatu perusahaan, mengakibatkan tidak adanya hubungan antara pelaporan CSR dengan naik atau tidaknya nilai dari perusahaan (Puspitasari, 2011). Pelaksanaan CSR merupakan strategi jangka panjang, sehingga untuk menikmati hasil dari pelaksanaan CSR yang tercermin dalan kinerja perusahaan membutuhkan waktu cukup lama. Sehingga, pelaksanaan CSR dalam jangka waktu yang pendek dapat dikatakan wajar ketika tidak berpengaruh terhadap nilai perusahaan. Dari hasil penelitian yang telah dilakukan, dapat diindikasikan bahwa besar atau kecilnya CSR tidak berdampak pada nilai perusahaan. hal ini diakibatkan oleh beberapa fenomena, diantaranya, kecenderungan investor dalam membeli saham serta rendahnya pengungkapan CSR yang dilakukan oleh perusahaan (Ermayanti, 2019). Penelitian ini menunjukkan hasil yang sama dengan penelitian yang dilakukan Nurhayati (2012), Setianingrum (2015), Islahuddin (2008) dan Yustia (2014) yang menemukan bahwa variabel CSR tidak berpengaruh terhadap nilai perusahaan.

\section{SIMPULAN, KETERBATASAN DAN SARAN \\ Simpulan}

Penelitian ini dilakukan untuk mengetahui pengaruh Intellectual capital dan CSR terhadap nilai perusahaan yang terdaftar di BEI tahun 2018-2020. Berdasarkan hasil temuan penelitian dapat disimpulkan bahwa: (1) Intellectual capital berpengaruh pada nilai perusahaan, (2) CSR tidak berpengaruh pada nilai perusahaan.

\section{Keterbatasan}

Terdapat beberapa keterbatasan pada penelitian ini, diantaranya: (1) penelitian ini hanya berfokus pada perusahaan pertambangan sehingga belum dapat mewakili seluruh perusahaan yang terdaftar di BEI. (2) pengaruh yang mampu diberikan oleh variabel independen hanya sebesar 5,2\%, sehingga banyak faktor lain di luar variabel ini yang masih harus digunakan untuk mengukur nilai perusahaan.

\section{Saran Untuk Penelitian Selanjutnya}

Berdasarkan kesimpulan dan keterbatasan yang telah dijelaskan sebelumnya, maka saran yang dapat diberikan oleh peneliti atara lain: 1) Penelitian-penelitian selanjutnya agar dapat menggunakan variabel lainnya seperti kinerja keuangan sebagai variabel independen yang mempengaruhi nilai perusahaan. dengan semakin banyak variabel yang digunakan, maka nilai perusahaan secara keseluruhan akan makin tergambarkan dengan jelas. 2) Penelitian selanjutnya diharapkan untuk meneliti lebih dari tiga tahun karena semakin panjang tahun penelitian maka semakin tampak keadaan perusahaan seutuhnya. 


\section{DAFTAR PUSTAKA}

Angelina, D. \& Suryaningsih, R. (2015). The Effect of Environtmental Performance and Corporate Social Responsibility Disclosure Towards Financial Performance (Case Study to Manufacture, Infrastructure, and Service Companies That Listed At Indonesia Stock Exchange). Procedia - Social and Behavioral Sciences, 211, 348 $-355$

Anindita, Prita dan Retno. 2017. Pengungkapan Corpotare Social Responsibility, Profitabilitas dan Nilai Perusahaan. Simposium Nasional Akuntansi XX. Jember.

Anita, Teddy Junarli, Meiliana. 2017. Pengungkapan Corpotare Social Responsibility: Pengaruh Struktur Kepemilikan dan karakteristik Perusahaan. Simposium Nasional Akuntansi XX. Jember.

Anindita, Prita dan Retno. 2017. Pengungkapan Corpotare Social Responsibility, Profitabilitas dan Nilai Perusahaan. Simposium Nasional Akuntansi XX. Jember.

Anita, Teddy Junarli, Meiliana. 2017. Pengungkapan Corpotare Social Responsibility: Pengaruh Struktur Kepemilikan dan karakteristik Perusahaan. Simposium Nasional Akuntansi XX. Jember.

Annisa Nur Afifah. 2013. Analisis Pengaruh Intellectual Capital Terhadap Nilai Perusahaan Yang Terdaftar di JII Periode 2010-2013. Skripsi. Fakultas Syariah dan Hukum. Universitas Islam Negeri Syarif Hidayatullah Jakarta.

Bambang Sudiyatno dan Elen Puspitasari, 2010. Tobin's $Q$ dan Altman Z-Score Sebagai Indikator Pengukuran Kinerja Perusahaan. Kajian Akuntansi. Vol. 2. No. 1.

Bontis, N., Keo w, W.C.C, \& Richardson, S. 2000. Intellectual Capital and Business Performance in Malaysia Industries. Journal of Intellec-tual Capital , 85100.

Bontis, N. 1998. Intellectual Capital: An Exploratory Study That Develops Measures. Management Decision, 85-100.

Chariri, Anis dan Imam Ghozali. 2007. Teori Akuntansi. Fakultas Ekonomi: Universitas Diponogoro Semarang.

Chen, M. C. 2005. An Empirical Investigation of The Relationship Between Intellectual Capital and Firms' Market Value and Financial Performance. Journal of Intellectual Capital , 159-176.

Devi, Sunitha. Et al. 2016. Pengaruh Enterprise Risk management Disclosure Dan Intellectual Capital Disclosure Pada Nilai Perusahaan. Simposium Nasional Akuntansi XIX. Lampung.

Deegan, C. 2004. Financial Accounting Theory. Sydney: McGraw-Hill Book Company.

Edvison, L. (1997). Developing intellectual capital at Skandia. Long Range Planning, Vol.30 No.3, 366-73.

Edvison, L. \& Malone, M.S. (1997). Intellectual Capital: Realizing Your Company's True Value By Findings Its Hidden Brainpower. Harper Bussiness, New York.

Felicia helga Inez. 2016. Analisis Pengaruh Intellectual Capital Dan Corporate Social Responsibility Terhadap Nilai Perusahaan Perbankan (Studi Pada Bank Umum Konvensional Go Public yang Terdaftar di BursaEfek Indonesia Tahun 2013-20 15). Skripsi. Fakultas Ilmu Sosial dan Ilmu Politik. Universitas Lampung.

Firer, S. S. \& Williams, M. (2003). Intellectual Capital and Traditional Measures of Corporate Performance. Journal of Intellectual Capital, 4(3), 348-360.

Ghozali, I. 2011. Aplikasi Analisis Multivariate dengan Program IBM SPSS 19 (edisi kelima). Semarang: Universitas Diponegoro.

Gujarati, D. 2003. Ekonometrika Dasar. Edisi Keenam. Erlangga. Jakarta. 
Hadiwijaya, Rendy Cahyo. 2013. "Pengaruh Modal Intelektual terhadap Nilai Perusahaan dengan Kinerja Sebagai Intervening". Skripsi. Universitas Diponogoro, Semarang.

Hackston, D., \& Milne, M. J. (1996). Some determinants of social and environmental disclosures in New Zealand companies. Accounting, Auditing \& Accountability Journal,9 (1), 77-108.

http://finance.detik.com/read/2012/07/14/154959/1965426/4/ribuan-perusahaantambang-di-ri-hanya-10-yang-jalankan-Corporate social responsibility. diakses pada tanggal 14 Desember pukul 14.30

Issabella Octaviany G. 2015. Pengaruh Intellectual Capital Disclosure Terhadap Nilai Perusahaan Dengan Goodcorporate Governance Sebagai Variabel Moderasi. Jurnal TEKUN/Vol VI/, No,01, Maret 2015: 96-111.

Jensen, \& Meckling. 1976. Theory of The Firm: Managerial Behavior, Agency Cost and Ownership Structure. Journal of Finance Economics Vol. 3 .

Jo, H. \& Harjoto, M. A. (2011). Corporate Governance and Firm Value: The Impact of Corporae Social Responsibility. Journal of Business Ethics, 103 (3), 351-383.

Kartika Hendra Titisari, Eko Suwardi, Doddy Setiawan. 2010. Corporate Social Responsibility (CSR) dan Kinerja Keuangan. Simposium Nasional Akuntansi XIII. Purwokerto

M. Iqbal Hasan. 2010. Pokok - Pokok Materi Statistik 2 (Statistik Inferensif). Jakarta : PT Bumi Aksara

Muhammad Iqbal. 2007. Analisis Pemangku Kepentingan Dan Implementasinya Dalam Pembangunan. Jurnal Litbang, 26(3) : 89-99.

Marfuah dan Kandera Rineko Nindya. 2017. Peran Pengungkapan Corpotare Social Responsibility, Kepemilikan Manajerial, dan Keemilikan Institusional dalam Memoderasi pengaruh Kinerja Keuangan Terhadap Nilai Perusahaan. Simposium Nasional Akuntansi XX. Jember.

Ni Wayan Rustiarini. 2010. Pengaruh Corporate Governance pada Hubungan Corporate Social Responsibility dan Nilai Perusahaan. Simposium Nasional Akuntansi XIII. Purwokerto.

Norma Fauzia. 2016. Pengaruh Intellectual Capital, Karakteristik Perusahan, dan Corpotare Social Responsibility. Jurnal Ilmu dan Riset Akuntansi Vol.5 No.4 April.2016.

Nuhatama. D. U. 2014. "Pengaruh Intellectual Capital dan Intellectual Capital Disclosure Terhadap Nilai Perusahaan Dengan Kinerja Keuangan Sebagai Variabel Intervening." Skripsi, Fakultas Ekonomi Universitas Islam Indonesia.

Nurhayati, I., Poerwati, T., dan Kartika, A. 2019. Dampak Moderasi Profitabilitas dan Laverage Terhadap Pengaruh CSR Pada Nilai Perusahaan Di Indonesia. Prosiding SENDI_U 2019.

Nurlela \& Islahudin. 2008. Pengaruh Corporate Social Responsibility Terhadap Nilai Perusahaan Dengan Prosentase Kepemilikan Manajemen Sebagai Variabel Moderating. Simposium Nasional Akuntansi XI.

Nuryaman. 2015. The Influence of Intellectual Capital on The Firm's Value with The Financial Performance as Intervening Vaiale. Procedia Social and Behaviour Scienes, 211, 292-298.

Putri, A.J., Agustin, H., \& Helmayunita, N. (2019). Pengaruh Intellectual Capital terhadap Nilai Perusahaan dengan Profitabilitas Sebagai Variabel Intervening. Jurnal Eksplorasi Akuntansi. 1(3). Seri F. 1541-1555. 
Paskah Simanungkalit. 2015. Pengaruh Intellectual Capital Terhadap Nilai Perusahaan Dengan Kinerja Keuangan Sebagai Variabel Intervening (Studi Pada Perusahaan Manufaktur yang Terdaftar di BEI Periode 2009-2013). Skripsi. Fakultas Ekonomika dan Bisnis. Universitas Diponegoro.

Pemerintah Republik Indonesia. PP RI No 47 Tahun 2012 Tentang Tanggung Jawab Sosial dan Lingkungan Perseroan Terbatas (2012).

Pramelasari, Yosi Metta. 2010. "Pengaruh Intellectual Capital Terhadap Nilai Pasar dan Kinerja Keuangan Perusahaan”. Skripsi Universitas Diponegoro, Semarang.

Pulic, A. 1998. Measuring the Performance of Intellectual Potential in Knowledge .Paper presented at the 2nd McMaster Word Congress on Measuring by Austrian Team for Intellectual

Pulic, A. \& M. Bornemann. (1999). The physical and intellectual capital of Austrian banks.

Rendy Cahyo Hadiwijaya dan Abdul Rohman. 2013. Pengaruh Intellectual Capital Terhadap Nilai Perusahaan dengan Kinerja Keuangan Sebagai Variabel Intervening. Diponegoro Journal of accounting Vol.2 No.3 Tahun 2013..

Rhenald Kasali. (1994). Manajemen Public Relation: konsep dan aplikasinya di Indonesia. Jakarta: Pustaka Utama Graffiti.

Rimba Kusumadilaga. 2010. Pengaruh Corporate social responsibility Terhadap Nilai Perusahaan Dengan Profitabilitas Sebagai Variabel Moderating (Studi Empiris pada Perusahaan Manufaktur yang terdaftar di Bursa Efek Indonesia). Skripsi. Fakultas Ekonomi. Universitas Diponogoro.

Rozeff, M. S. (1982). Growth, Beta and Agency Cost as Determinants of Dividend Payout Ratios. Journal of Financial Research, 5 (3), 249-259.

Sakandarrumidi. (1999). Bahan-Bahan Galian Industri. Yogyakarta: Gajah Mada University Press.

Sandra Aulia Z dan TB MH Idris Kartawijaya. 2011. Analisis Pengungkapan Triple Bottom Line dan Faktor yang Mempengaruhi; Lintas Negara Indonesia dan Jepang. Simposium Nasional Akuntansi XIV. Aceh.

Sawarjono, T., \& Kadir, A. P. 2003. Intellectual Capital: Perlakuan, Pengukuran dan Pelaporan (sebuah library Reasearch). Journal Akuntansi dan Keuangan, 3557.

Sheila Ramadhani Nurdinia. 2013. Pengaruh Intellectual Capital Terhadap Nilai Perusahaan. Kertas Kerja. Fakultas Ekonomika Dan Bisnis. Universitas Kristen Satya Wacana.

Stewart, T. A. 1991. Brainpower: How Intellectual Capital is Becoming. Fortune.

Sutopoyudo. 2009. Pengaruh Penerapan Corporate social responsibility terhadap Profitabilitas Perusahaan. Sutopoyudo's weblog at http://www.wordpress.com

Schadewitz, H. \& Niskala, M. (2010). Communication via Responsibility Reporting and Its Effect on Fim Value in Finlandia. Corporate Social Responsibility and Environmental Management, 17 (2), 96-106.

Tan. , H.P., Plowman, D. Dan Hancock, P. (2007). Intellectual Capital And Financial Returns Of Companies. Journal of Intellectual Capital, Vol. 8 No. 1, 76-95.

Ulum, I. 2009. Intelectual Capital; Konsep dan Kajian Empiris. Yogyakarta: Graha Ilmu.

Ulum. 2008. Intellectual Capital dan Kinerja Keuangan Perusahaan; Suatu Analisis dengan Pendekatan Partial Least Squares. Pontianak: SNA XI. 
Undang - undang No. 40 Tahun 2007 Tentang Perseroan Terbatas Bab IV pasal 66 dan Bab V pasal 74.

Wahidwati. 2002. Pengaruh Kepemilikan Manajerial Dan kepemilikan Institusional Pada Kebijakan Hutang Perusahaan: Sebuah Perspektif Theory Agency. Jurnal Riset Akuntansi Indonesia, Vol. 5, No.1, Januari: Hal1-16.

Weston, J., \& Brigham, E. F. 1993. Manajemen Keuangan: Jilid 1. Jakarta: Salemba Empat.

Williams, M. 2001. Is Intellectual Capital Performance and Disclosure Practices? Journal of Intellectual Capital , 192-203.

Wibowo dan Faradiza. 2014. Dampak Pengungkapan Sustinability Report Terhadap Kinerja Keuangan dan Pasar Perusahaan. Simposium Nasional Akuntansi XVII. Mataram

Yoppy Palupi Puraningsih. 2015. Analisis Perbandingan Kinerja Keuangan Antara Perusahaan Pertambangan Milik Pemerintah (BUMN) dengan Perusahaan Pertambangan Swasta yang Terdaftar Di Bursa Efek Indonesia. Laporan Penelitian.

Yuskan \& Dhia Novita. 2014. Analisis Pengaruh Intellectual Capital Terhadap Nilai Perusahaan Dengan Kinerja Keuangan Sebagai Variabel Intervening Pada Perusahaan Perbankan Di Indonesia. Jurnal Manajemen dan Bisnis Sriwijaya Vol.12 No.4 Desember.

Yustisia Puspaningrum. 2014. Pengaruh Corporate social responsibility Dan Kepemilikan Manajerial Terhadap Nilai Perusahaan Dengan Profitabilitas Dan Ukuran Perusahaan Sebagai Variabel Moderating (Studi Empiris pada Perusahaan Pertambangan di Bursa Efek Indonesia). Skripsi. Fakultas Ekonomi. Universitas Negeri Yogyakarta.

www.idx.co.id 